\title{
Water Exchange Calculations Using the Salt Conservation Law in Ayla Lagoons in the Northern Gulf of Aqaba, Red Sea
}

\author{
Riyad Manasrah \\ Department of Coastal Environment, Faculty of Marine Sciences, The University of Jordan-Aqaba, Aqaba, \\ Jordan \\ Email: r.manasrah@ju.edu.jo
}

Received 9 March 2015; accepted 14 April 2015; published 15 April 2015

Copyright (C) 2015 by author and Scientific Research Publishing Inc.

This work is licensed under the Creative Commons Attribution International License (CC BY). http://creativecommons.org/licenses/by/4.0/

c) (i) Open Access

\section{Abstract}

The salt conservation law was applied, for the first time, in order to compare the real and calculated values of water outflow $\left(\mathrm{m}^{3} / \mathrm{s}\right)$ and residence time (days) in the lagoons of Ayla Oasis at the northernmost tip of the Gulf of Aqaba. The aim is to obtain the scientific bases of monitoring beside the real observation in areas that could not be measured directly by the current meters. The real measurements of water current by Acoustic Doppler Current Profiler (ADCP) workhorse 600 kHz, salinity and density by the Conductivity, Temperature and Depth meter (CTD 19plusV2), were collected during the period June 2012-May 2013. The statistical analysis was performed using Statview (5.0) software. The results revealed highly significant correlation between the real and calculated values for both water flow $(r=0.90 ; P=0.0001)$ and residence time $(r=0.89 ; P<$ 0.0001). Hence, the salt conservation law can be used to calculate the outflow and residence time of seawater inside the lagoons, particularly at areas that could not be accessed for direct current measurements. The differences between the real and calculated values of the water outflow (1.85 $\left.\pm 1.71 \mathrm{~m}^{3} / \mathrm{s}\right)$ and residence time $(0.80 \pm 0.72$ days $)$ should be taken into consideration to correct the calculated values.

\section{Keywords}

Salt Conservation Law, Residence Time, Artificial Lagoons, Gulf of Aqaba

\section{Introduction}

Coastal ecosystems, located along the margins of continents and oceanic islands, are areas of high productivity. 
They play vital roles in supporting human wellbeing because of their immense biological resources and the lifesupporting services they provide [1] [2]. Nearly 500 million people (including nearly 30 million poor people) depend directly and indirectly on coral reefs for their livelihoods, food and other resources [3]. Further, it is estimated that up to $80 \%$ of the global fish catch is directly or indirectly dependent on mangroves [4] [5].

Lagoon ecosystem is one of the shallow water ecosystems that are separated by barrier or coral from larger water systems, which is characterized by predominant sand substratum [6]. Lagoons occupy about $15 \%$ of the earth's coastal zones [7].

Coastal lagoons and estuaries represent water bodies along the coast that formed during rises in sea level, which was particularly high during the early Holocene (12,000 - 8000 years ago) and slowed down some 6000 years ago [8]. Many authors [8]-[10] call them "ephemeral" as they are continuously changing with the passing of time [4].

Lagoons and estuaries are extremely important in the sustenance of coastal fisheries. Many edible shell fish and fish are found in lagoons, estuaries and their associated habitats such as mangroves and seagrasses. The relatively calm habitats of lagoons allow for the practice of traditional and artisanal fisheries [4] [11].

Physical properties of the lagoons are important abiotic factors in ecosystem. Lagoons respond rapidly to any changes in temperature and/or salinity of the water because their areas are small with shallow depth [12]. Some physical and chemical aspects of the coastal lagoons of the Red Sea have been studied [13]-[15].

The characteristics that make shallow lagoons and estuaries highly productive are the long water residence times, the cycling of nutrients before they are flushed to the sea which makes them very vulnerable to overenrichment by nutrients and its attendant consequences [10].

Estuaries and coastal lagoons are driven by tides, river input, wind stress, and heat balance at the surface, but respond unequally to these forcing functions because of differences in geomorphology. Whereas circulation, mixing and exchange have been studied extensively in coastal plain estuaries, these processes have been less well synthesized for coastal lagoons. The main threats that face lagoons and estuaries are the point and nonpoint source pollution [16]. However, the dependence of water quality and eutrophication on flushing, hydrodynamic turnover and physical dynamics is of prime importance for planning and implementation of coastal management strategies in coastal lagoons [17].

Artificial lagoons can be of different nature, such as, Closed Lagoons or Inland Lagoons, which are a kind of artificial lake without direct connection to the sea, however with seawater being pumped and circulated in the lagoon system; and Open Lagoons or Tidal Lagoons, which are connected to the sea by one or more tidal inlets [18].

The energetic balance of a coastal lagoon depends principally on the access channel configuration controlling the exchange rates of materials, residence time and water quality [19].

In this study, the water flow and residence time of waters inside lagoons (artificial) of the Ayla Oasis (Figure 1) were calculated for the first time using the salt conservation law. This law depends mostly on the basic physical properties (salinity and density) and the pumping rates. The objective of this study is to compare the calculated values with the real observation of water flow and residence time, and to use the salt conservation law as a base of monitoring beside the real observation in areas that could not be measured directly by the current meters.

\section{Methodology}

\subsection{Study Site}

The Gulf of Aqaba (Figure 1) is a semi-enclosed basin that extends over a length of $180 \mathrm{~km}$ with a width between 5 and $25 \mathrm{~km}$ (average of $16 \mathrm{~km}$ ). The deepest point in the Gulf reaches $1825 \mathrm{~m}$ with an average depth of $800 \mathrm{~m}$. The Gulf is connected to the Red Sea by the Strait of Tiran, which has a sill depth of about $265 \mathrm{~m}$. While much of the Gulf is deep (>1800 m), the northern sector has a relatively shallow shelf adjacent to the major population centers [20]-[25].

The Jordanian coast $(27 \mathrm{~km})$ on the Gulf of Aqaba is fringed by discontinuous belt of reefs separated by sandy bottoms that are usually covered by seagrass meadows [26]. The northern part of the Jordanian coast, which is in front of the study area (Ayla lagoons), is characterized by sandy bottoms that are covered by seagrass beds and absence of hard substrate and reef-building corals [27]. The study area is actually close to the center of two main towns (Aqaba and Eilat), and it was selected due to its importance and environmental significant for the surrounding countries, because it is substantially under various active developments. The current active and rapid 


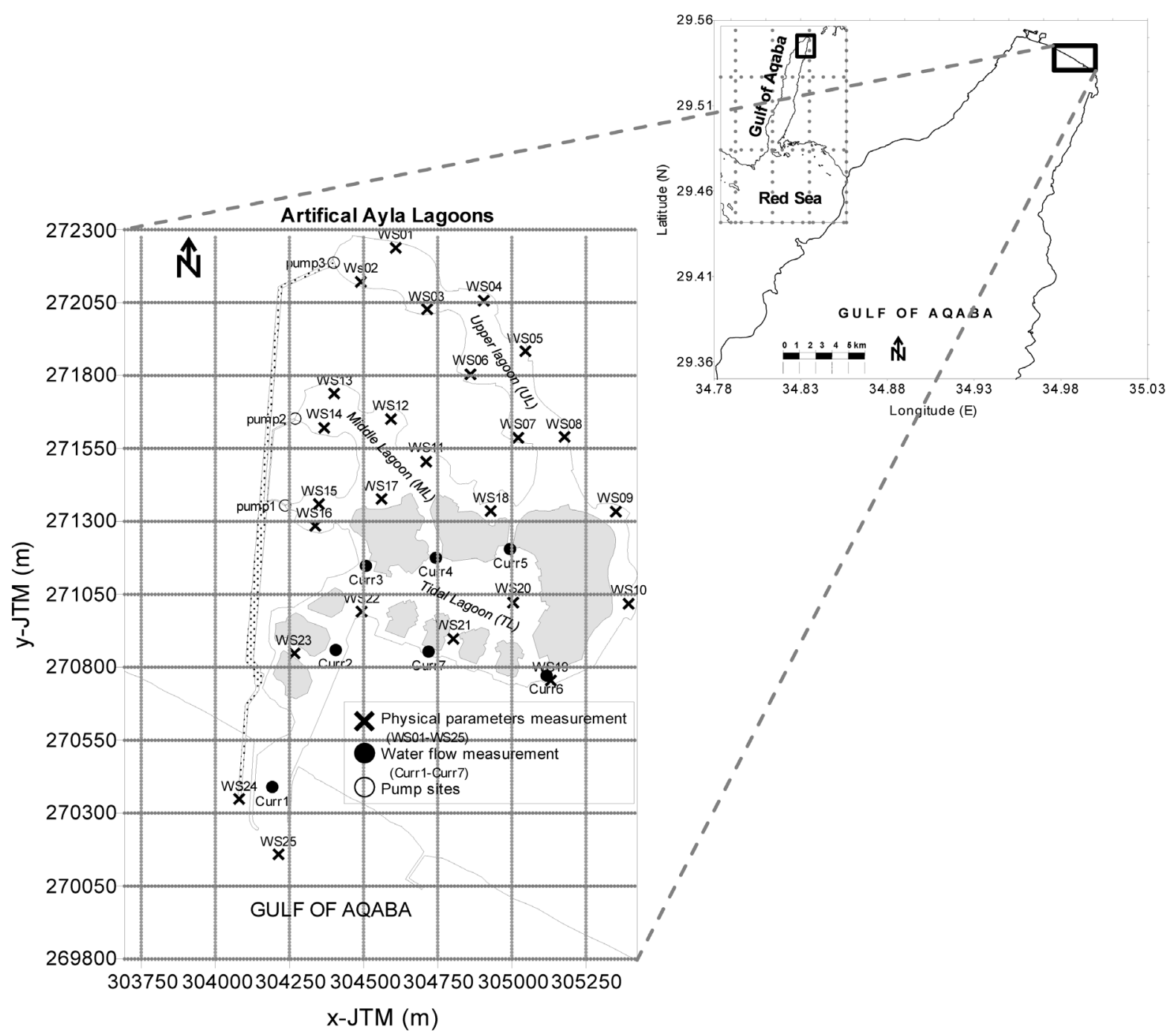

Figure 1. Map of study area and measurements sites in the lagoons of Ayla Oasis in the northern Gulf of Aqaba (After Manasrah 2015 [30]).

development including the establishment of artificial lagoons at the northern end of the Gulf of Aqaba is expected to cause ocean pollutions at this area [28]-[30].

\subsection{Ayla Oasis}

Ayla Oasis is an artificial lagoons located at the northernmost tip of the Gulf of Aqaba with $235 \mathrm{~m}$ sea frontage onto the open sea (Figure 1). This enterprise was established based on the Master plan of the Aqaba Special Economic Zone (ASEZ). Ayla Oasis consisted of three lagoons; upper (UL), middle (ML) and tidal lagoons (TL). The UL and ML are at $+6.0 \mathrm{~m}$ and $+3.0 \mathrm{~m}$ above sea level, respectively, while the TL is directly connected to the open sea with same level. These lagoons created remarkable $17 \mathrm{~km}$ of new seafront to the Aqaba city. Pumping stations are used to maintain reasonable water quality in the lagoons. Water is being pumped up into the UL and ML, and then flow under gravity over the various cascading weirs discharging at various points into the TL, and from there to the open sea (Table 1).

\subsection{Data Collection}

The water flow was measured monthly at seven sites (Curr1-Curr7) inside the TL using Acoustic Doppler Current Profiler (ADCP) workhorse $600 \mathrm{kHz}$ during the period June 2012-May 2013. Salinity and density were 
Table 1. The detailed operational scenarios of pumping system into the lagoons of Ayla Oasis in the northern Gulf of Aqaba.

\begin{tabular}{cccc}
\hline Period & Flow into UL by Pump $\mathbf{3}\left(\mathbf{m}^{\mathbf{3}} \cdot \mathbf{s}^{-\mathbf{1}}\right)$ & Flow into ML by Pumps $\mathbf{1}+\mathbf{2}\left(\mathbf{m}^{\mathbf{3}} \cdot \mathbf{s}^{-1}\right)$ & Total flow $\left(\mathbf{m}^{\mathbf{3}} \cdot \mathbf{s}^{-1}\right)$ \\
\hline 1-May-12 to 15-Jul-12 & 6 & 4.2 & 10.2 \\
16-Jul-12 to 10-Jan-13 & 3.6 & 2.52 & 6.12 \\
10-Jan-13 to 1-Jun-13 & 3 & 3.5 & 6.5 \\
\hline
\end{tabular}

measured monthly at 25 sites in all lagoons using Conductivity, Temperature and Depth meter (CTD 19plusV2) during the same period as above (Figure 1). The sites for current measurements (Curr1-Curr7) were selected at the connection channel between the TL with the open sea and the connection between the TL with the UL and ML. The purpose was to calculate the residence time of waters inside all lagoons as well as inside the UL and ML. The residence time of water in all lagoons was calculated by utilizing the results of current measurements at Curr1 site.

\subsection{Salt Conservation Law}

Conservation of mass and salt can be used to obtain very useful information about flows and residence time in the ocean. Salinity in a given region of the ocean can change due to river discharge, precipitation, freezing/ thawing, and evaporation. However, the overall amount of salt in the oceans remains relatively constant, i.e., salinity is a conservative property of seawater [31].

Because salt is not deposited or removed from the sea, conservation of salt requires that:

$$
\rho_{i} V_{i} S_{i}=\rho_{o} V_{o} S_{o}
$$

where $\rho_{i}\left(\mathrm{~kg} \cdot \mathrm{m}^{-3}\right), S_{i}$ (PSU) are the density and salinity of the water inflow, and $\rho_{o}\left(\mathrm{~kg} \cdot \mathrm{m}^{-3}\right), S_{o}(\mathrm{PSU})$ are density and salinity of the outflow, respectively (Figure 2). The $V_{i}$ and $V_{o}$ are the water inflow and outflow in $\mathrm{m}^{3} / \mathrm{s}$, respectively.

In this study, the salt conservation law was used in order to calculate the flow and residence time of seawater inside the three lagoons.

The residence time or flushing time $(R T)$ of the lagoons basin can be identified as the minimum time needed to completely flush the entire volume of water inside the lagoons. The residence time is determined from the rate of water outflow $(V)\left(\mathrm{m}^{3} / \mathrm{s}\right)$ from the basin and the volume of the basin $(\mathrm{Vol})\left(\mathrm{m}^{3}\right)$.

$$
R T=\mathrm{Vol} / \mathrm{V}
$$

\subsubsection{Implemented Calculations in the Upper Lagoon (UL)}

The salt conservation law in Equation (1) was used to calculate the outflow rate in the upper lagoon. Taking into account the several measurements of salinity and density near the connection channel between the UL and ML (Figure 3), the Equation (1) can be modified as:

$$
V_{o}=\frac{V_{i}\left(\rho_{1}+\rho_{2}\right)\left(S_{1}+S_{2}\right)}{\left(\rho_{18}+\rho_{9}\right)\left(S_{18}+S_{9}\right)}
$$

where:

$V_{o}$ : water outflow from the UL to the ML $\left(\mathrm{m}^{3} / \mathrm{s}\right)$.

$V_{i}$ : water inflow by pump3 to the UL $\left(\mathrm{m}^{3} / \mathrm{s}\right)$.

$\rho_{i}$ : density of water inflow at sites ws01, ws02 $\left(\mathrm{kg} / \mathrm{m}^{3}\right)$.

$S_{i}$ : salinity of water inflow at sites ws01, ws02 (PSU).

$\rho_{0}$ : density of water outflow waters at sites ws18, ws09 $\left(\mathrm{kg} / \mathrm{m}^{3}\right)$.

$S_{0}$ : salinity of water outflow at sites ws18, ws09 (PSU).

The residence time $(R T)$ of waters inside the UL was calculated using Equation (2) as:

$$
R T(\mathrm{UL})=\mathrm{Vol} / \mathrm{V}_{o}
$$

where, $\mathrm{Vol}$ is the water volume of the $\mathrm{UL}\left(\sim 374,000 \mathrm{~m}^{3}\right)$ and $V_{o}$ is the water outflow from the UL into the ML. 


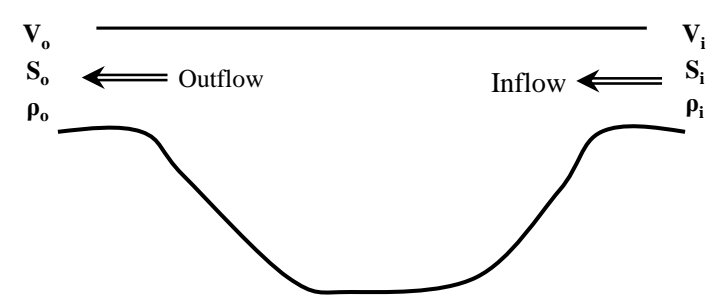

Figure 2. Balance between water inflow and outflow in water body basin.

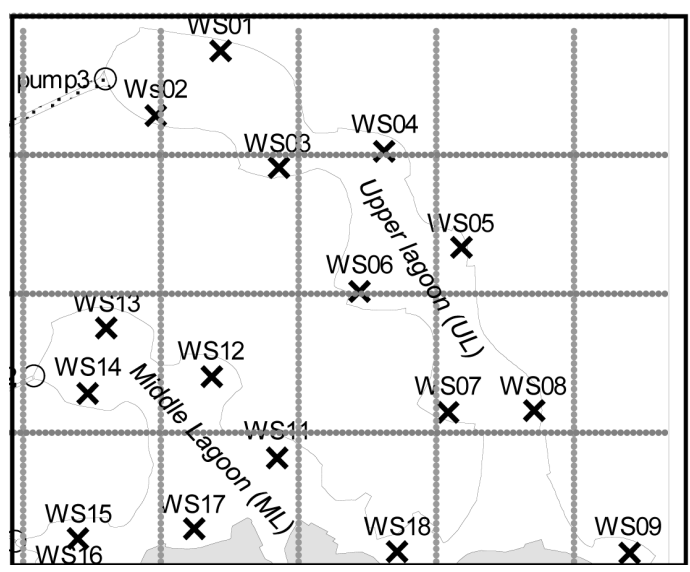

Figure 3. Map of the upper lagoon (UL) in the lagoons of Ayla Oasis in the northern Gulf of Aqaba.

\subsubsection{Implemented Calculations in the Middle Lagoon (ML)}

Similar to the upper lagoon, the salt conservation law in Equation (1) was used to calculate the outflow rate in the Middle lagoon (ML). Besides, the equation considered the average values of density and salinity for the water inflow and outflow in order to obtain more realistic results (Figure 4). Therefore, the Equation (1) was modified to the following:

$$
V_{o}=\frac{4\left[V_{i}\left(\rho_{18}+\rho_{9}\right)\left(S_{18}+S_{9}\right)+\operatorname{pump} 1\left(\rho_{15}+\rho_{16}\right)\left(S_{15}+S_{16}\right)+\operatorname{pump} 2\left(\rho_{13}+\rho_{14}\right)\left(S_{13}+S_{14}\right)\right]}{\left(\rho_{10}+\rho_{19}+\rho_{20}+\rho_{22}\right)\left(S_{10}+S_{19}+S_{20}+S_{22}\right)}
$$

where:

$V_{o}$ : water outflow of ML into TL $\left(\mathrm{m}^{3} / \mathrm{s}\right)$.

$V_{i}$ : water inflow of UL into ML $\left(\mathrm{m}^{3} / \mathrm{s}\right)$.

$\rho_{i}$ : density of water inflow at sites ws09, ws13, ws14, ws15, ws16, ws18 $\left(\mathrm{kg} / \mathrm{m}^{3}\right)$.

$S_{i}$ : salinity of water inflow at sites ws09, ws13, ws14, ws15, ws16, ws18 (PSU).

$\rho_{0}$ : density of water outflow at sites ws10, ws19, ws20, ws22 $\left(\mathrm{kg} / \mathrm{m}^{3}\right)$.

$S_{0}$ : salinity of water outflow at sites ws10, ws19, ws20, ws22 (PSU).

Pump 1 and pump 2: water inflow by pump1 and pump 2 into ML ( $\left.\mathrm{m}^{3} / \mathrm{s}\right)$.

The residence time $(R T)$ of waters inside the ML was calculated using Equation (2) as:

$$
R T(\mathrm{ML})=\mathrm{Vol} / \mathrm{V}_{\mathrm{o}}
$$

where, $\mathrm{Vol}$ is the water volume of the ML $\left(\sim 246,500 \mathrm{~m}^{3}\right)$ and $V_{o}$ is the water outflow from the ML into the TL.

\subsubsection{Implemented Calculations in the Tidal Lagoon (TL)}

Similar to the previous calculations in UL and ML, salt conservation law in Equation (1) was used to calculate the flow and residence time in the TL. The average values of density and salinity for the water inflow and outflow were utilized in order to get more realistic results (Figure 5). Therefore, the Equation (1) can be modified as the following: 


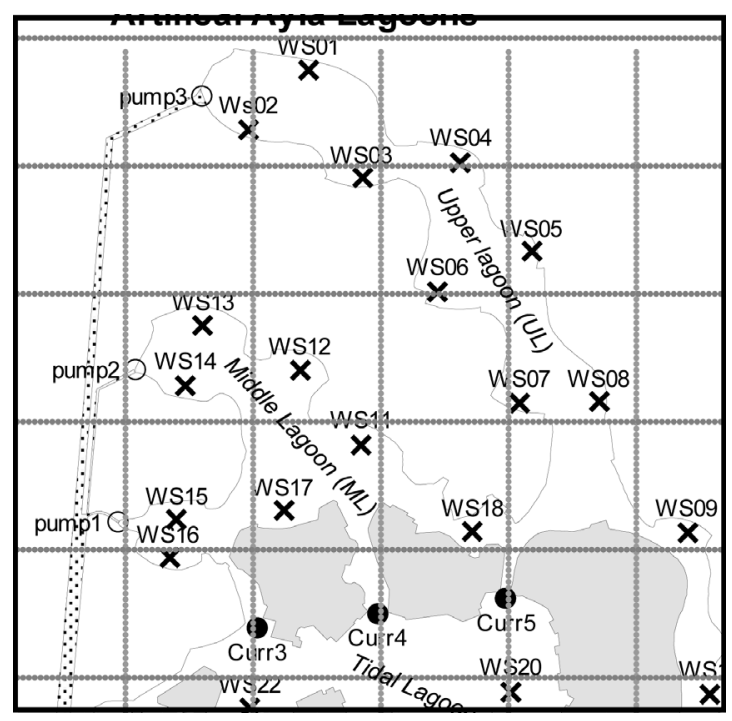

Figure 4. Map of the middle lagoon (ML) in the lagoons of Ayla Oasis in the northern Gulf of Aqaba.

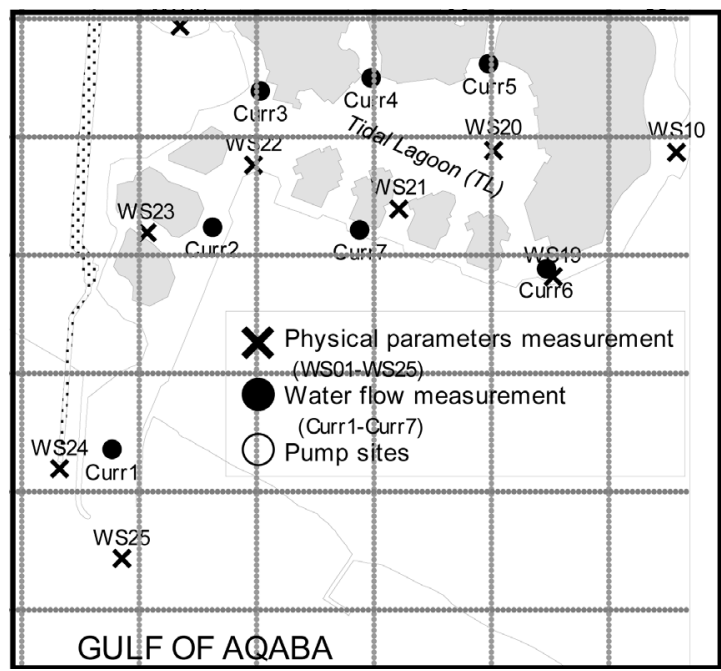

Figure 5. Map of the tidal lagoon (TL) in the lagoons of Ayla Oasis in the northern Gulf of Aqaba.

$$
V_{o}=\frac{V_{i}\left(\rho_{10}+\rho_{19}+\rho_{20}+\rho_{22}\right)\left(S_{10}+S_{19}+S_{20}+S_{22}\right)}{\left(16 \rho_{24} S_{24}\right)}
$$

$V_{o}$ : water outflow of TL into the open sea $\left(\mathrm{m}^{3} / \mathrm{s}\right)$.

$V_{i}$ : water inflow of ML into TL $\left(\mathrm{m}^{3} / \mathrm{s}\right)$.

$\rho_{i}$ : density of water inflow at sites ws10, ws19, ws20, ws22 $\left(\mathrm{kg} / \mathrm{m}^{3}\right)$.

$S_{i}$ : salinity of water inflow at sites ws10, ws19, ws20, ws22 (PSU).

$\rho_{0}$ : density of water outflow at sites ws $24\left(\mathrm{~kg} / \mathrm{m}^{3}\right)$.

$S_{0}$ : salinity of water outflow at sites ws24 (PSU).

The residence time $(R T)$ of waters inside all lagoons was calculated using Equation (2) as:

$$
R T(\mathrm{ALL})=\mathrm{Vol} / \mathrm{V}_{\text {o }}
$$

where, $\mathrm{Vol}$ is the water volume of all lagoons $\left(\sim 1,525,000 \mathrm{~m}^{3}\right)$ and $V_{o}$ is the water outflow from the TL into the open sea. 


\subsection{Statistical Analysis}

The correlation test between the real and calculated values of water outflow from all lagoons into the open sea and the residence time of waters inside all lagoons during the period June 2012-May 2013 was performed using Statview (5.0) software in order to check the validity of using the salt conservation law in Ayla lagoons.

\section{Results and Discussions}

By the use of salt conservation law and its application in water bodies of the different lagoons of Ayla Oasis, the values of flow water $\left(\mathrm{m}^{3} / \mathrm{s}\right)$ and residence time (days) were generated to each lagoon and then data were compared between the calculated with the real that was measured.

\subsection{Upper Lagoon (UL)}

The results of the outflow and residence time of waters in the UL (Table 2, Figure 6) revealed that the maximum and minimum outflow values were 5.96 and $2.98\left(\mathrm{~m}^{3} / \mathrm{s}\right)$ in June 2012 and May 2013, respectively. The average value of outflow was $3.53 \pm 0.82\left(\mathrm{~m}^{3} / \mathrm{s}\right)$.

The maximum and minimum residence time of waters inside the UL was 1.45 and 0.72 (days) as measured in May 2013 and June 2012, respectively. The average value of residence time was $1.27 \pm 0.21$ (days).

The maximum outflow $\left(5.96 \mathrm{~m}^{3} / \mathrm{s}\right)$ and minimum residence time (0.72 days) in the UL was more obvious during the period of highest pumping rate by pump no. 3 in June 2012, which was $6 \mathrm{~m}^{3} / \mathrm{s}$. In general, the flow rate and residence time has an inverse relationship.

The water outflow decreased after June 2012 to the range $\left(2.97-3.59 \mathrm{~m}^{3} / \mathrm{s}\right)$ due to the significant reduce in pumping rate after June 2012 to about $\left(3-3.6 \mathrm{~m}^{3} / \mathrm{s}\right)$.In general, the residence times results indicate that the conditions at the UL in term of water quality were good with an expected secure environment.

\subsection{Middle Lagoon (ML)}

The results of the outflow from ML into the TL and residence time of waters in both ML and UL (Table 3, Figure 7) revealed that the maximum and minimum outflow values was 10.14 and $6.04\left(\mathrm{~m}^{3} / \mathrm{s}\right)$ in June 2012 and December 2012, respectively. The average value of outflow was $6.57 \pm 1.14\left(\mathrm{~m}^{3} / \mathrm{s}\right)$.

The maximum and minimum residence time of waters inside the ML and UL was 1.19 and 0.71 (days) in December 2012 and June 2012, respectively. The average value of residence time was $1.11 \pm 0.13$ (days).

Similar to the UL, the maximum outflow from the ML into TL $\left(10.14 \mathrm{~m}^{3} / \mathrm{s}\right)$ and minimum residence time ( 0.71 days) in both ML and UL was in the period of highest pumping rate by pumps ( 1 - 3) in June 2012, which was $10.2 \mathrm{~m}^{3} / \mathrm{s}$.

The water outflow decreased after June 2012 to the range $\left(6.10-6.51 \mathrm{~m}^{3} / \mathrm{s}\right)$, which was due to the significant reduction of pumping rates after June 2012 to about $\left(6.12-6.5 \mathrm{~m}^{3} / \mathrm{s}\right)$. However, the residence time results in both ML and UL indicate that the environment conditions were good.

\subsection{Tidal Lagoon (TL)}

The results of the outflow from TL into the open sea and residence time of waters in all lagoons (Table 4, Figure 8) revealed that the maximum and minimum outflow values were 10.24 and $6.10\left(\mathrm{~m}^{3} / \mathrm{s}\right)$ in June 2012 and December 2012, respectively. The average value of outflow was $6.62 \pm 1.15\left(\mathrm{~m}^{3} / \mathrm{s}\right)$.

The maximum and minimum residence time of waters inside all lagoons was 4.07 and 2.42 (days) in December 2012 and June 2012, respectively. The average value of residence time was $3.82 \pm 0.45$ (days).

Similar to the UL and ML, the maximum outflow from the TL into open sea $\left(10.24 \mathrm{~m}^{3} / \mathrm{s}\right)$ and minimum residence time (2.42 days) in all lagoons was in the period of highest pumping rate by pumps no. ( 1 - 3 ) in June 2012, which was $10.2 \mathrm{~m}^{3} / \mathrm{s}$.

The water outflow decreased after June 2012 to the range $\left(6.10-6.51 \mathrm{~m}^{3} / \mathrm{s}\right)$, due to the significant reduction of pumping rates after June 2012 to about $\left(6.12-6.5 \mathrm{~m}^{3} / \mathrm{s}\right)$.

The residence time of all water body of the three lagoons was longer about 3.4 folds compared to the UL and ML. This because the water volume of all lagoons is about 2.5 folds compared to the UL and ML and there is no other inflow waters source into the TL except the origin source from pumps no. (1 - 3). 
Table 2. Water outflow ( $\mathrm{m}^{3} / \mathrm{s}$ ) of UL into the ML and residence time (days) of the UL during June 2012-May 2013 in the lagoons of Ayla Oasis in the northern Gulf of Aqaba.

\begin{tabular}{ccc}
\hline Date & Vout $\mathbf{( U L )}\left(\mathbf{m}^{\mathbf{3}} / \mathbf{s}\right)$ & Residence Time (UL) (Days) \\
\hline 28-Jun-12 & 5.96 & 0.72 \\
$19-J u l-12$ & 3.59 & 1.20 \\
$22-$ Aug-12 & 3.57 & 1.21 \\
$13-$ Sep-12 & 3.58 & 1.20 \\
$13-$ Oct-12 & 3.58 & 1.21 \\
20-Nov-12 & 3.57 & 1.21 \\
16-Dec-12 & 3.55 & 1.22 \\
16-Jan-13 & 3.00 & 1.44 \\
16-Feb-13 & 2.99 & 1.45 \\
16-Mar-13 & 2.98 & 1.45 \\
10-Apr-13 & 2.99 & 1.44 \\
08-May-13 & 2.97 & 1.45 \\
\hline
\end{tabular}

Table 3. Water outflow ( $\mathrm{m}^{3} / \mathrm{s}$ ) of the ML into the TL and residence time (days) of UL and ML during June 2012-May 2013 in the lagoons of Ayla Oasis in the northern Gulf of Aqaba.

\begin{tabular}{ccc}
\hline Date & Vout $\mathbf{( M L )}\left(\mathbf{m}^{\mathbf{3}} / \mathbf{s}\right)$ & Residence Time $\mathbf{( M L} \boldsymbol{\&}$ TL) (Days) \\
\hline 28-Jun-12 & 10.14 & 0.70 \\
19-Jul-12 & 6.07 & 1.18 \\
22-Aug-12 & 6.09 & 1.18 \\
13-Sep-12 & 6.08 & 1.18 \\
13-Oct-12 & 6.07 & 1.18 \\
20-Nov-12 & 6.06 & 1.18 \\
16-Dec-12 & 6.04 & 1.19 \\
16-Jan-13 & 6.48 & 1.10 \\
16-Feb-13 & 6.41 & 1.12 \\
16-Mar-13 & 6.47 & 1.11 \\
10-Apr-13 & 6.46 & 1.11 \\
08-May-13 & 6.46 & 1.11 \\
\hline
\end{tabular}

Table 4. Water outflow ( $\mathrm{m}^{3} / \mathrm{s}$ ) of the TL into the open sea and residence time (days) of all lagoons during June 2012-May 2013 in the lagoons of Ayla Oasis in the northern Gulf of Aqaba.

\begin{tabular}{ccc}
\hline Date & Vout $\mathbf{( M L )}\left(\mathbf{m}^{\mathbf{3}} / \mathbf{s}\right)$ & Residence Time (ML \& TL) (Days) \\
\hline 28-Jun-12 & 10.24 & 2.42 \\
19-Jul-12 & 6.14 & 4.04 \\
22-Aug-12 & 6.14 & 4.04 \\
13-Sep-12 & 6.13 & 4.05 \\
13-Oct-12 & 6.13 & 4.05 \\
20-Nov-12 & 6.10 & 4.07 \\
16-Dec-12 & 6.09 & 4.07 \\
16-Jan-13 & 6.52 & 3.81 \\
16-Feb-13 & 6.46 & 3.84 \\
16-Mar-13 & 6.47 & 3.83 \\
10-Apr-13 & 6.50 & 3.81 \\
08-May-13 & 6.51 & 3.81 \\
\hline
\end{tabular}




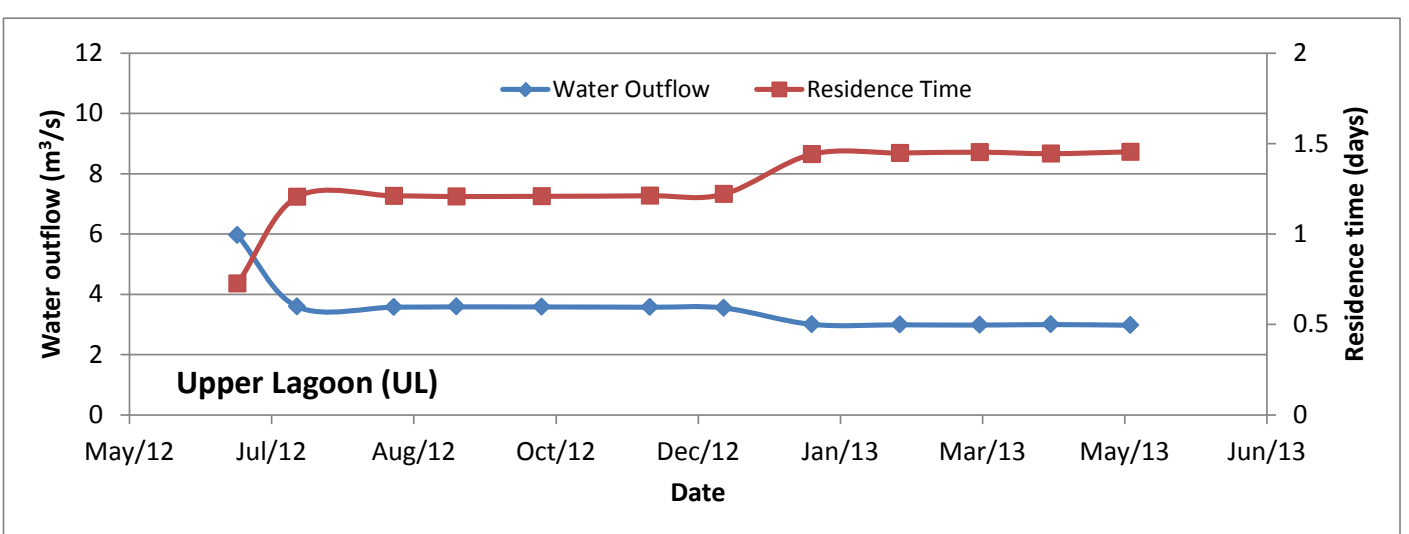

Figure 6. Time series of calculated values of water outflow $\left(\mathrm{m}^{3} / \mathrm{s}\right)$ and residence time (days) in the UL during the period June 2012-May 2013 in the lagoons of Ayla Oasis in the northern Gulf of Aqaba.

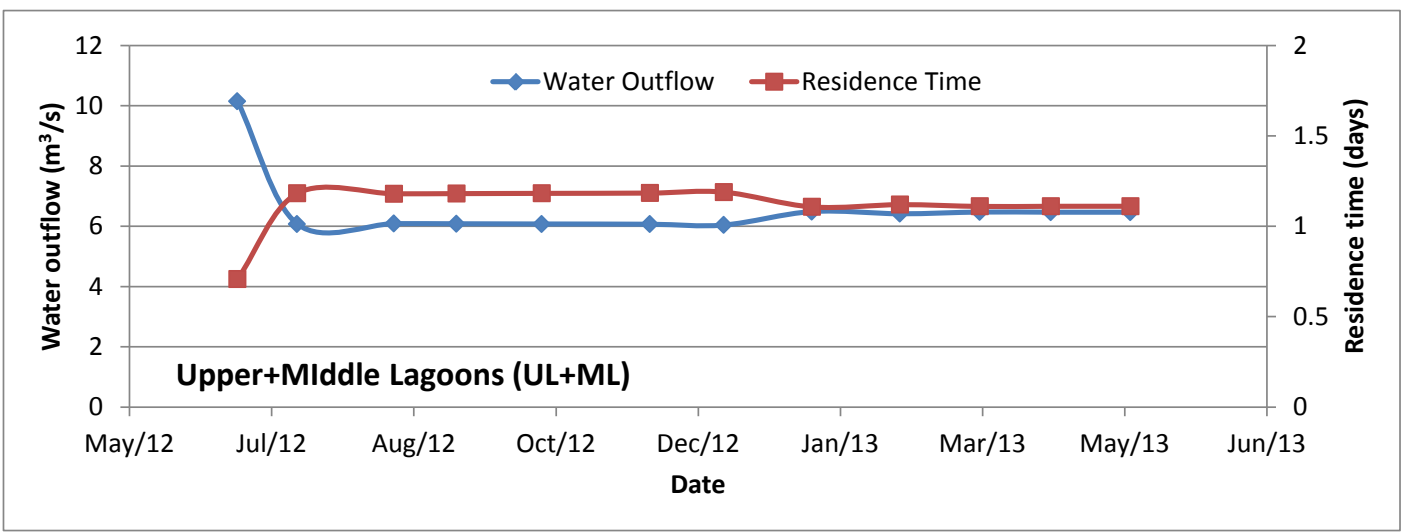

Figure 7. Time series of calculated values of water outflow $\left(\mathrm{m}^{3} / \mathrm{s}\right)$ and residence time (days) in the UL and ML during the period June 2012-May 2013 in the lagoons of Ayla Oasis in the northern Gulf of Aqaba.

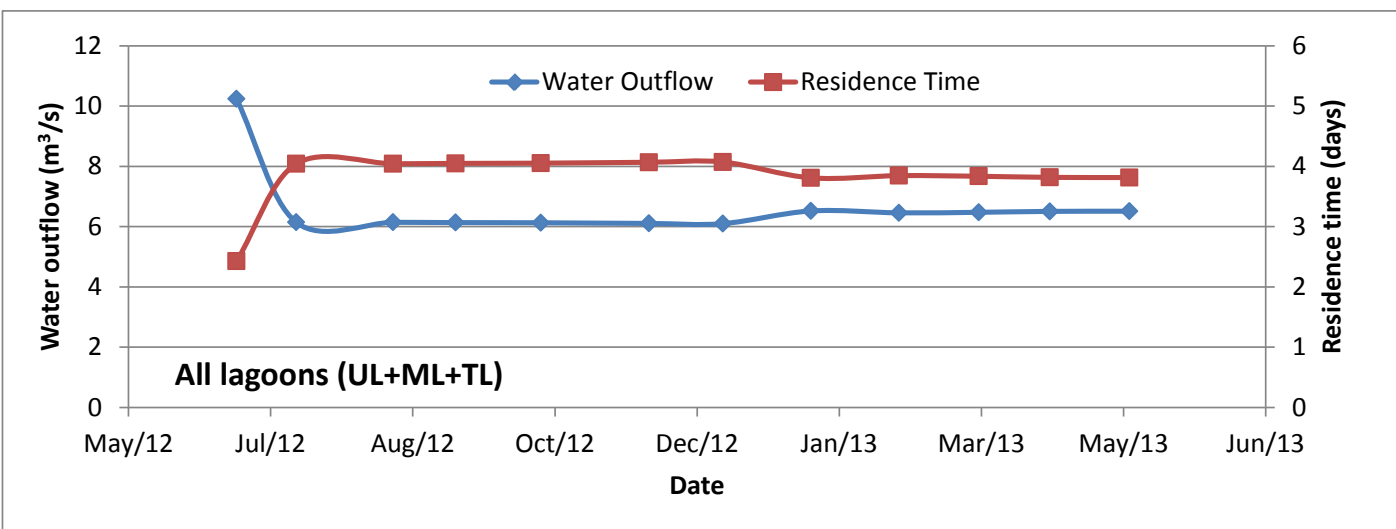

Figure 8. Time series of calculated values of water outflow $\left(\mathrm{m}^{3} / \mathrm{s}\right)$ and residence time (days) in all lagoons (UL, ML and TL) during the period June 2012-May 2013 in the lagoons of Ayla Oasis in the northern Gulf of Aqaba.

Although there are some semi-enclosed areas that did not exchange waters efficiently inside the lagoons, which was not representing an actual obstacle for the overall water exchange between the lagoons and the open sea. The results revealed an excellent and secured environmental condition that expected to prevail in the future.

The results of the present study revealed an excellent condition prevail inside all these artificial lagoons with an expected sustainability of such environmental conditions in the future. The results of average residence time 
of seawater in the lagoons suggested good conditions in water quality and even more than a proper time needed to ensure a complete flushing in the lagoons in order to secure high quality of the environmental conditions.

\subsection{Statistical Correlations}

The maximum and minimum values of the water outflow and residence time were ignored in correlation test to ensure not including any possible error and to enhance the results of the correlation, which statistically accepted. The maximum value was recorded in the first month of measurements (June 2012), where we assumed that some error occurred as it was the first trial implements this kind of measurements. The lowest value was in November 2012, due to the shut down of water pumps as the meteorological conditions were bad and unusual during that time.

The correlation between the real and calculated values of water outflow (Table 5; Figure 9) statistically revealed a highly significant relationship (correlation coefficient " $\mathrm{r}=0.90$ "; correlation probability test "P $=$ 0.0001"). In addition, the same test for the residence time (Table 5; Figure 10) showed a highly significant relationship ( $r=0.89$; $\mathrm{P}<0.0001$ ) between the real and calculated values. In general, these results indicate that the principle of salt conservation law can be applied to calculate the water outflow and residence time in the lagoons of Ayla Oasis.

Table 5. Real observation and calculated values of water outflow $\left(\mathrm{m}^{3} / \mathrm{s}\right)$ from the lagoons into the open sea and the residence time (days) of all lagoons during the period June 2012-May 2013 in the lagoons of Ayla Oasis in the northern Gulf of Aqaba.

\begin{tabular}{|c|c|c|c|c|}
\hline \multirow{2}{*}{ Date } & \multicolumn{2}{|c|}{ Outflow $\left(\mathrm{m}^{3} / \mathrm{s}\right)$ - All Lagoons } & \multicolumn{2}{|c|}{ Residence Time (Days) - All Lagoons } \\
\hline & Real & Calculated & Real & Calculated \\
\hline 28-Jun-12 & 16.62 & 10.24 & 1.49 & 2.42 \\
\hline 18-Jul-12 & 10.5 & 6.14 & 2.36 & 4.04 \\
\hline 22-Aug-12 & 9.88 & 6.14 & 2.51 & 4.04 \\
\hline 17-Sep-12 & 9.17 & 6.13 & 2.71 & 4.05 \\
\hline 17-Oct-12 & 9.59 & 6.12 & 2.59 & 4.05 \\
\hline 19-Nov-12 & 5.94 & 6.10 & 4.18 & 4.07 \\
\hline 17-Dec-12 & 8.38 & 6.09 & 2.96 & 4.07 \\
\hline 16-Jan-13 & 7.25 & 6.52 & 3.43 & 3.81 \\
\hline 17-Feb-13 & 6.68 & 6.45 & 3.72 & 3.84 \\
\hline 18-Mar-13 & 7.33 & 6.47 & 3.39 & 3.83 \\
\hline 21-Apr-13 & 6.17 & 6.50 & 4.02 & 3.82 \\
\hline 20-May-13 & 6.71 & 6.51 & 3.70 & 3.81 \\
\hline
\end{tabular}

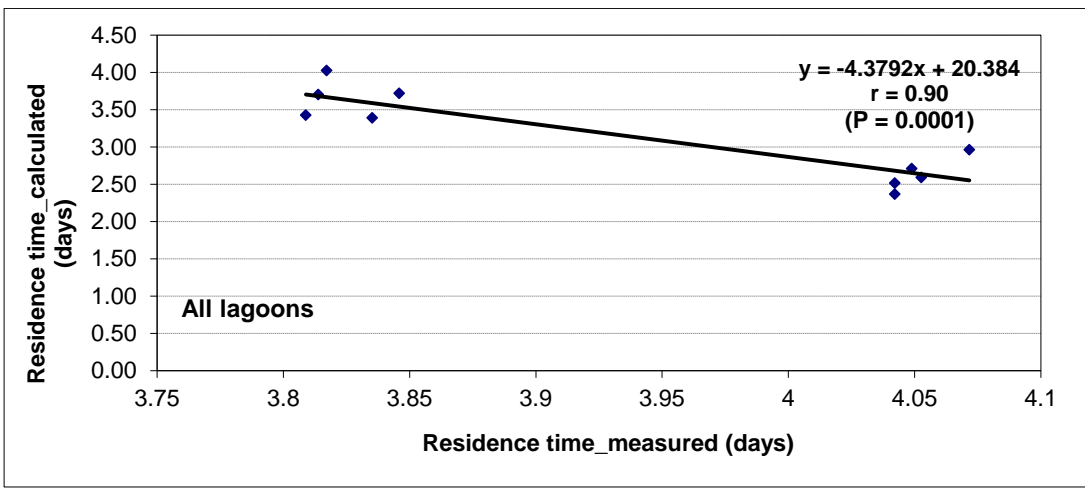

Figure 9. Relationship between real and calculated values of water outflow $\left(\mathrm{m}^{3} / \mathrm{s}\right)$ from TL into open sea during the period June 2012-May 2013 in the lagoons of Ayla Oasis in the northern Gulf of Aqaba. 


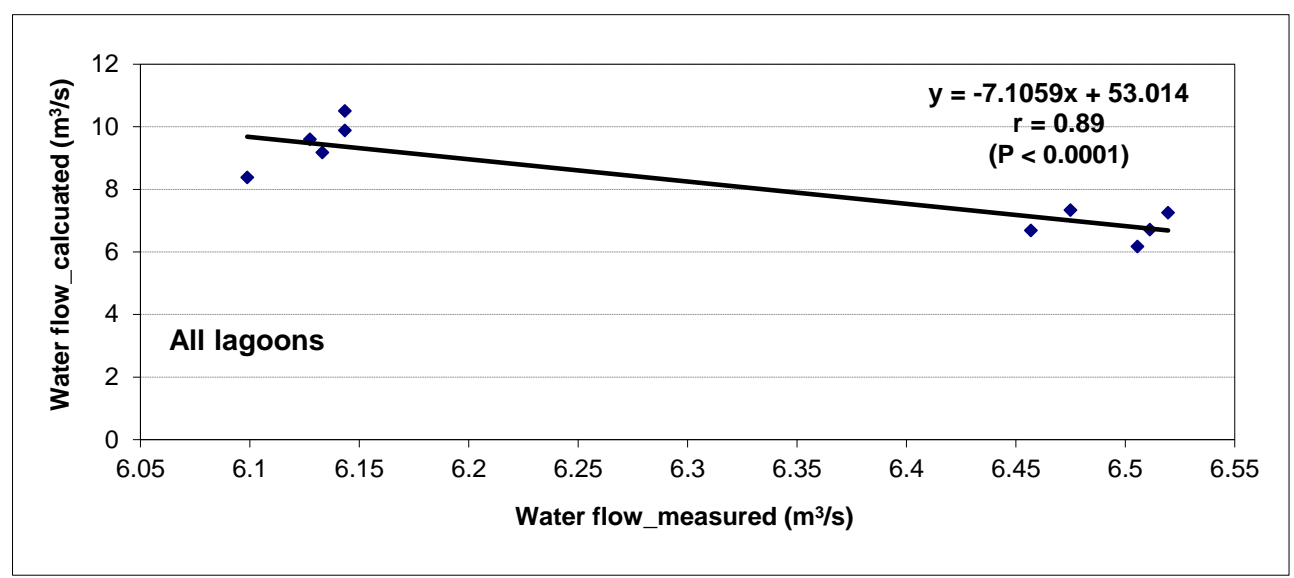

Figure 10. Relationship between real and calculated values of residence time (days) of waters in all lagoons during the period June 2012-May 2013 in the lagoons of Ayla Oasis in the northern Gulf of Aqaba.

Although there were significant relationship between the real measurements and calculated values of water outflow and residence time, there were also differences between the real and calculated values. In relation to water outflow, the average difference between the real and calculated values was $1.85 \pm 1.71 \mathrm{~m}^{3} / \mathrm{s}$, where the calculated values were always lower. On the other hand, the average difference between the real and calculated values of residence time was $0.80 \pm 0.72$ days, where the calculated values were always longer.

Several studies expressed the effect of the wind driven force and tidal force on current pattern near the study site. Brenner et al. [32] reported that wind events in the northern Gulf of Aqaba drive upwelling in the eastern side and downwelling in the western side. Manasrah et al. [28] found anticlockwise current rotation with depth, during summer and autumn seasons, near the study area, which may be related to the Ekman wind drift in the coastal region with vertical wall [33] [34]. They predict that steady wind stress acting together with the Coriolis force will produce a transport of water to the right of the wind. Moreover, the current pattern might be related to the effect of bottom topography, which might have been directed the currents to flow parallel to its shape, i.e. parallel to the shoreline [28]. Basically, the differences between the real and calculated values of water outflow and residence time could be attributed to the fact that the results by the utilization of the salt conservation low was not taking into account the effect of wind driven force and tidal force. Therefore, further investigation is needed to calculate the strength of these forces in the generalized calculations of outflow and residence time.

However, it can be concluded that the salt conservation law can be used for calculation of the outflow and residence time of seawater inside the lagoons, particularly in areas that could not be reached for direct current measurements. The differences between the real and calculated values for the water outflow $\left(1.85 \pm 1.71 \mathrm{~m}^{3} / \mathrm{s}\right)$ and residence time ( $0.80 \pm 0.72$ days) should be taken into consideration to correct more precisely the calculated values.

\section{Acknowledgements}

The author would like to thank the technical staff at the Marine Science Station and Ayla Oasis Company for their help in fieldwork. Special thanks are due to Mr. Mysara Al-Amor, Ms. Delara Alkayyal for their help and support.

\section{References}

[1] World Resources Institute (WRI) (2001) Pilot Analysis of Global Ecosystems. Coastal Ecosystems. WRI, USA, 93 pages. http://dbccc.onep.go.th/climate/attachments/article/96/page_coastal.pdf

[2] UNISDR/UNDP (2012) A Toolkit for Integrating Disaster Risk Reduction and Climate Change Adaptation into Ecosystem Management of Coastal and Marine Areas in South Asia. Outcome of the South Asian Consultative Workshop on "Integration of Disaster Risk Reduction and Climate Change Adaptation into Biodiversity and Ecosystem Management of Coastal and Marine Areas in SouthAsia”, held in New Delhi on 6 and 7 March 2012. UNDP, New Delhi, 173 pages. 
[3] Wilkinson, C. (2004) Status of Coral Reefs of the World, 2004 (Vol. 1). Australian Institute of Marine Science, Townsville, xiv+301 pp.

[4] Miththapala, S. (2013) Lagoons and Estuaries. Coastal Ecosystems Series (Vol. 4). vi + 73 pp. IUCN Sri Lanka Country Office, Colombo.

[5] Sullivan, C. (2005) The Importance of Mangroves. http://ufdc.ufl.edu/UF00093446/00028/1

[6] Hutomo, M. and Moosa, M.K. (2005) Indonesian Marine and Coastal Biodiversity: Present Status. Indian Journal of Marine Sciences, 34, 88-97.

[7] UNESCO (1981) Tenth Report of the Joint Panel on Oceanographic Tables and Standards. UNESCO Technical Papers in Marine Sciences, No. 36.

[8] Kjerfve, B. (1994) Coastal Lagoon Processes (Elsevier Oceanography Series, 60), 1-8.

[9] De Wit, R. (2011) Biodiversity of Coastal Lagoon Ecosystems and Their Vulnerability to Global Change. In: Grillo, O. (Ed.), Ecosystems Biodiversity, 29-40.

http://www.intechopen.com/books/ecosystems-biodiversity/biodiversity-of-coastal-lagoon-ecosystems-andtheir-vulner ability-to-globalchange

[10] Kennish, M.J. and Paerl, H.W. (2010) Coastal Lagoons Critical Habitats of Environmental Change. In: Kennish, M.J. and Paerl, H.W. (Eds.). Coastal Lagoons: Critical Habitats of Environmental Change (Marine Science Series), CRC Press, Boca Raton, 1-16.

[11] Björk, M., Short, F., Mcleod, E. and Beer, S. (2008) Managing Seagrasses for Resilience to Climate Change. IUCN, Gland, $56 \mathrm{p}$.

[12] Smith, N.P. (1977) Meteorological and Tidal Exchange between Corpus Christi Bay, Texas and the Northwestern Gulf of Mexico. Estuarine and Coastal Marine Science, 5, 511-520. http://dx.doi.org/10.1016/0302-3524(77)90098-6

[13] Al-Barakati, A. (2010) Some Hydrographic Features of Rabigh Lagoon along the Eastern Coast of the Red Sea. Journal of King Abdulaziz University-Marine Sciences, 21, 123-132. http://dx.doi.org/10.4197/Mar.21-1.7

[14] Meshal, A.H. (1987) Hydrography of a Hypersaline Coastal Lagoon in the Red Sea. Estuarine, Coastal and Shelf Science, 24, 167-175. http://dx.doi.org/10.1016/0272-7714(87)90063-1

[15] El-Sayed, M.Kh. (1987) Chemistry of Modern Sediments in Hypersaline Lagoon, North of Jeddah, Red Sea. Estuarine, Coastal and Shelf Science, 25, 467-480. http://dx.doi.org/10.1016/0272-7714(87)90038-2

[16] Loague, K. and Corwin, D.L. (2005) Point and Non-Point Source Pollution. In: Anderson, M.G., Ed., Encyclopedia of Hydrological Sciences, John Wiley \& Sons, Ltd., Chichester, 1427-1440.

[17] Kjerfve, B. and Magill, K.E. (1989) Geographic and Hydrodynamic Characteristics of Shallow Coastal Lagoons. Marine Geology, 88, 187-199. http://dx.doi.org/10.1016/0025-3227(89)90097-2

[18] Mangor, K. (2004) Shoreline Management Guidelines. DHI Water \& Environment, Hørshølm, Denmark.

[19] Smith, N.P. (1994) Water, Salt and Heat Balance of Coastal Lagoons. Elsevier Oceanography Series, 60, 69-101.

[20] Hall, J.K. (1975) Bathymetric Chart of the Straits of Tiran. Israel Journal of Earth Sciences, 24, 69-72.

[21] Hall, J.K. and Ben-Avraham, Z. (1978) New Bathymetric Map of the Gulf of Eilat (Aqaba). In: The Tenth International Conference on Sedimentol, Vol. 1, Jerusalem, 9-14 July 1978, 285 (Abst.).

[22] Hulings, N.C. (1989) A Review of Marine Science Research in the Gulf of Aqaba. Marine Science Station, Aqaba.

[23] David, S. and Walter, S. (1996) Global Bathymetric Prediction for Ocean Modeling and Marine Geophysics. http://topex.ucsd.edu/marine topo/text/

[24] Wessel, P. and Smith, W. (1996) A Global Self-Consistent, Hierarchical, High-Resolution Shoreline Database. Journal of Geophysical Research, 101, 8741-8743.

[25] Manasrah, R., Al-Horani, F., Rasheed, M., Al-Rousan, S. and Khalaf, M. (2006) Patterns of Summer Vertical and Horizontal Currents in Coastal Waters of the Northern Gulf of Aqaba, Red Sea. Estuarine, Coastal and Shelf Science, 69, 567-579. http://dx.doi.org/10.1016/j.ecss.2006.05.024

[26] UNDEP/IUCN (1988) Coral Reefs of the World. UNEP Regional Seas Directories and Bibliographies. IUCN, Gland, Switzerland and Cambridge, UK/UNEP, Nairobi, Kenya.

[27] Al-Rousan, S., Rasheed, M., Khalaf, M.A. and Badran, M. (2005) Ecological and Geochemical Characteristics of Bottom Habitats at the Northern Jordanian Coast of the Gulf of Aqaba. Chemistry and Ecology, 21, 227-239. http://dx.doi.org/10.1080/02757540500211277

[28] Manasrah, R., Zibdah, M., Al-Ougaily, F., Yusuf, N. and Al-Najjar, T. (2007) Seasonal Changes of Water Properties and Current in the Northernmost Gulf of Aqaba, Red Sea. Ocean Science Journal, 42, 103-116. 
http://dx.doi.org/10.1007/BF03020878

[29] Badran, M., Manasrah, R. and Rasheed, M. (2006) Sea-Water Seasonal Changes at a Heavy Tourism Investment Site on the Jordanian Northern Coast of the Gulf of Aqaba, Red Sea. Chemistry and Ecology, 22, 425-435. http://dx.doi.org/10.1080/02757540600917344

[30] Manasrah, R. (2015) Physical Properties and Exchange System of Seawater in Ayla Lagoons in the Northern Gulf of Aqaba, Red Sea. Fresenius Environmental Bulletin, 24 (in press).

[31] Bryden, H.L. and Kinder, T.H. (1991) Recent Progresses in Strait Dynamics. Reviews of Geophysics, 29, 617-631.

[32] Brenner, S., Rosentroub, Z. and Bishop, Y. (1991) Current Measurements in the Gulf of Elat 1990/91. Report H12/91, Israel Oceanographic and Limnological Research, Haifa.

[33] Price, J.F., Weller, R.A. and Schudlich, R.R. (1987) Wind-Driven Ocean Currents and Ekman Transport. Science, 238, 1534-1538. http://dx.doi.org/10.1126/science.238.4833.1534

[34] Krauss, W. (1993) Ekman Drift in Homogeneous Water. Journal of Geophysical Research, 98, 20187-20209. http://dx.doi.org/10.1029/93JC01898 